\title{
Model Mitigasi Kebakaran Berbasis Masyarakat : Kajian Kualitatif pada Aparat Pemerintah dan LSM
}

\section{Fatmah}

\begin{abstract}
Abstrak
Lingkungan masyarakat kota yang bebas kebakaran dapat tercipta melalui upaya pencegahan dan pemadaman kebakaran dini. Penelitian ini bertujuan mengembangkan model mitigasi kesiapsiagaan kebakaran berbasis masyarakat. Metoda kualitatif wawancara mendalam dilakukan terhadap 30 informan terpilih di Jabodetabek meliputi aparat kecamatan, kelurahan, Lembaga Swadaya Masyarakat, dan Suku Dinas Pemadam Kebakaran. Mayoritas informan mengenal organisasi Barisan Sukarelawan Kebakaran, tetapi dalam pelaksanaan ditemukan beberapa kendala antara lain meliputi tidak ada honorarium, status pekerjaan, dan anggota penduduk musiman. Hal tersebut berakibat banyak anggota yang berhenti dan sulit merekrut anggota baru. Bentuk upaya pencegahan kebakaran yang dilakukan masyarakat meliputi simulasi, penyuluhan, dan pelatihan bahaya kebakaran, serta menjadi anggota Barisan Sukarelawan Kebakaran. Tiap wilayah mempunyai bentuk yang bervariasi sesuai dengan aturan yang berlaku di masyarakat karena masih bersifat regional serta belum dilegitimasikan dalam Undang-Undang Nasional. Alternatif model berbasis masyarakat yang terbaik adalah memberdayakan Barisan Sukarelawan Kebakaran mengingat program tersebut telah berjalan dan dikenal masyarakat. Diharapkan model ini lebih mudah diterima masyarakat karena menjadi bagian program pembangunan di beberapa wilayah. Dukungan masyarakat yang kuat terhadap Barisan Sukarelawan Kebakaran menentukan kelancaran pelaksanaan di lapangan.
\end{abstract}

Kata kunci : Model, pemberdayaan, mitigasi, kebakaran

\begin{abstract}
Urban environment which is free from fire can be created through early fire prevention and controlling efforts. The research objective was to develop community-based model in mitigation of fire preparedness. Depth interviews were conducted in the selected 30 informants at Jakarta, Bogor, Depok, Tangerang, and Bekasi cities. They came from sub-district authorities, villages, non government organizations, and Fire Government Institution staffs (Sudin Damkar). The majority of informants had familiarity with the organization, namely BALAKAR. However, its implementation had some constraints such as no provision of salary, employment status, and seasonal residents were attached to the members themselves. Consequently, many members were resigned and it was difficult to recruit new members. Type of fire prevention efforts undertaken in community were participating on fire simulation, extension, and training, and to be member of BALAKAR. However, the shapes were still scattered because each region had its own form depend on rules in society and had not yet legitimized in a national law because on regional level. The best alternative community-based model was empowering BALAKAR because of this program is still running and known by community . It was expected that the model will be accepted easily by community for being part of development programs in several areas. Later on, strong support from the community will determine the successful of BALAKAR implementation in the field.
\end{abstract}

Key words : Model, empowerment, mitigation, fire 
Dalam upaya mencegah atau meminimalkan potensi dampak bencana kebakaran pada masa mendatang diperlukan perencanaan program mitigasi dan kesiagaan terhadap bencana kebakaran. Mitigasi adalah upaya mengeliminasi, menurunkan/meminimalkan risiko bahaya bencana pada populasi yang rentan. Lingkup mitigasi meliputi eliminasi dan reduksi risiko serta transmisi tanggung jawab. Fokus mitigasi adalah mengeliminasi atau membatasi kemungkinan kejadian bencana, dan menurunkan kerentanan populasi. Kesiagaan terhadap potensi bencana adalah suatu bentuk upaya peningkatan kemampuan masyarakat dalam merespon secara efektif ancaman dan dampak bencana dan segera pulih dari dampak jangka panjang. Partisipasi aktif masyarakat memainkan peran yang paling penting dalam aspek kesiagaan terhadap bencana. ${ }^{1}$

Salah satu jenis bencana yang sering terjadi di Indonesia adalah kebakaran. Sampai pertengahan Desember 2006, DKI Jakarta telah terjadi kebakaran 849 kali meliputi Jakarta Pusat (115), Jakarta Utara (158), Jakarta Barat (192), Jakarta Selatan (201), dan Jakarta Timur (183). Objek terbakar paling banyak adalah bangunan perumahan (371). Penyebab kebakaran paling tinggi adalah listrik (428). Kebakaran tersebut berakibat kerugian harta benda yang diperkirakan mencapai lebih dari Rp.132,7 miliar. $^{2}$ Berdasarkan data tersebut terlihat jelas bahwa berbagai kasus kebakaran yang terjadi masih berkutat di seputar bangunan perumahan dengan penyebab utama sistem kelistrikan.

Faktor kelalaian masyarakat mendominasi sebagai penyebab kebakaran. Hal tersebut memunculkan pertanyaan besar tentang ketidakpedulian masyarakat terhadap berbagai penyuluhan dan pendekatan yang dilakukan jajaran Dinas Pemadaman Kebakaran Daerah Khusus Ibukota Jakarta. Mengingat dalam satu wilayah kelurahan ditemukan kejadian kebakaran sampai belasan kali.

Kegiatan penanggulangan bencana yang efektif secara ideal dilakukan melalui tiga tahap kegiatan. Pertama, upaya pencegahan atau mitigasi dan kesiagaan pada saat sebelum terjadi bencana. Kedua, upaya penyelamatan pada saat terjadi bencana. Ketiga, upaya rehabilitasi dan rekonstruksi setelah kejadian bencana. Penanganan bencana di Indonesia cenderung kurang efektif antara lain sebagai akibat paradigma penanganan bencana yang bersifat parsial, sektoral dan kurang terpadu. Tanggapan terpusat pada upaya pemerintah yang masih terbatas pada pemberian bantuan fisik yang hanya dilakukan pada fase kedaruratan. Meskipun perhatian terhadap bencana terlihat meningkat, tetapi upaya tersebut perlu mendapatkan perhatian terutama berhubungan dengan antisipasi, rehabilitasi, dan mitigasi bencana yang masih memerlukan perencanaan, implementasi dan sosialisasi secara lebih baik. Berbagai kejadian kebakaran di DKI Jakarta memperlihatkan ketidaksiapan pemerintah dan masyarakat menghadapi bencana yang telah terjadi secara rutin. Masyarakat tam- paknya belum terlibat secara penuh dalam berbagai kegiatan mitigasi dan rehabilitasi bencana. Lembaga mitigasi bencana nasional tampaknya belum muncul dan berperan meskipun telah ada badan koordinasi penanggulangan bencana dengan kegiatan yang masih terbatas pada pendataan dan koordinasi secara umum.

Pemerintah masih menjadi lembaga utama pengelolaan bencana sehingga penanganan bencana masih menerapkan model birokrasi dan belum menjadi model komunitas. Meskipun organisasi yang bergerak di bidang bencana cukup banyak, tetapi jejaring dan koordinasi terlihat masih merupakan peluang karena masih banyak lembaga internasional, nasional, lokal, pemerintah, dan perguruan tinggi yang belum bergabung. Oleh sebab itu, masyarakat yang merasakan dampak langsung bencana kebakaran perlu dilibatkan dalam mitigasi dan kesiagaan bencana kebakaran. Upaya pemberdayaan masyarakat bertujuan untuk menurunkan risiko kejadian kebakaran di lingkungan pemukiman yang banyak menelan korban jiwa dan harta benda.

Suatu studi pendahuluan dilakukan oleh Fakultas Kesehatan Masyarakat Universitas Indonesia pada tahun 2008 untuk menganalisis peran LSM dalam mitigasi dan kesiagaan bencana kebakaran. ${ }^{3}$ Studi tersebut menemukan peran LSM dan organisasi pemerhati kebakaran yang rendah dalam mitigasi dan kesiagaan bencana kebakaran. Kiprah mereka lebih banyak ditekankan pada upaya tanggap darurat berupa pemulihan, rekonstruksi lingkungan dan korban bencana kebakaran. Namun, ditemukan upaya pengembangan kemandirian masyarakat dalam bencana kebakaran melalui kegiatan Sistem Ketahanan Kebakaran Lingkungan (SKKL). Perangkat utama SKKL adalah pembentukan Barisan Sukarelawan Kebakaran (BALAKAR) dengan masyarakat setempat yang berperan sebagai anggota dan pengurus. ${ }^{4}$ Namun, pembentukan BALAKAR belum dilaksanakan secara serentak di seluruh kelurahan wilayah Jabodetabek sebagai akibat upaya sosialisasi Dinas Pemadam Kebakaran Tingkat Propinsi yang masih rendah. Untuk itu, dibutuhkan studi eksplorasi pengembangan model pemberdayaan masyarakat selain BALAKAR dalam mitigasi dan kesiapsiagaan bencana kebakaran di wilayah Jabodetabek.

\section{Metode}

Penelitian ini dilakukan dengan pendekatan kualitatif dengan teknik diskusi kelompok terarah (DKT) dan wawancara mendalam (WM). Subyek penelitian yang terlibat sebagai informan wawancara mendalam meliputi aparat kelurahan, kecamatan, LSM pemerhati kebakaran, dan Suku Dinas/Dinas Pemadam Kebakaran. Masyarakat disertakan sebagai informan DKT yang meliputi unsur Rukun Warga (RW), Rukun Tetangga (RT), Pendidikan Kesejahteraan Keluarga (PKK), karang taruna, dan masyarakat korban kebakaran. Pengumpulan data di- 
lakukan pada periode Oktober - November 2009 di 18 kelurahan dan lima kecamatan di Kota Jabodetabek. Tenaga lapangan adalah mahasiswa FKM UI yang terlatih mengumpulkan data kualitatif. Triangulasi yang dilakukan untuk menjamin kualitas data merupakan bagian inheren dari penelitian yang meliputi triangulasi sumber dan triangulasi metode. Triangulasi sumber dilakukan dengan melibatkan dan membandingkan sumber informasi yang berbeda yang meliputi LSM, pemerintah, dan masyarakat. Triangulasi metode dengan membandingkan metode DKT dan wawancara mendalam. Data sekunder dikumpulkan melalui kajian review berbagai model berbasis masyarakat yang sudah dilaksanakan di lapangan seperti SKKL dengan instrumen BALAKAR atau Satuan Sukarelawan Kebakaran (SATLAKAR). Instrumen yang dipakai meliputi Standard Operating Procedure (SOP), Peraturan Pemerintah (PP), Undang-Undang (UU), dan semua dokumen kegiatan SKKL dan BALAKAR.

\section{Hasil}

Bagian pertama yang diidentifikasi adalah kebutuhan model pemberdayaan masyarakat dalam mitigasi kesiagaan kebakaran. Seluruh informan dari kelurahan di lima wilayah DKI Jakarta menyatakan bahwa warga masyarakat di lingkungan pemukiman memerlukan tujuan bersama menyelamatkan jiwa dan harta benda melalui berbagai upaya. Alasan yang dikemukakan para informan dari Jakarta Barat adalah pada musim hujan dan kemarau perlu diantisipasi bahaya kebakaran melalui penyuluhan dan rasa kebersamaan dalam menghadapi kebakaran yang kuat. Perlu dilakukan berbagai upaya mengatasi kebakaran. Informan beberapa kelurahan di Jakarta Selatan menyatakan bahwa masyarakat harus mempunyai persepsi yang sama bahwa kerugian akibat kebakaran tidak hanya bersifat pribadi tetapi juga masyarakat. Dengan demikian, masyarakat harus mengetahui berbagai upaya penanggulangan yang perlu dilakukan. Selain itu, kebakaran juga dapat terjadi pada semua pihak sehingga upaya pencegahannya memerlukan kebersamaan.

Masyarakat harus mempunyai kesamaan persepsi bahwa kebakaran tidak hanya merugikan individu tetapi juga masyarakat. Masyarakat perlu tahu cara penanggulangan kebakaran. (wakil lurah, 51 tahun).

Kebakaran yang dapat terjadi kepada siapa saja memerlukan kebersamaan untuk mencegahnya (wakil lurah, 42 tahun).

Upaya mencegah kebakaran di lingkungan pemukiman yang padat dengan jalan yang sempit merupakan alasan yang kuat kebutuhan upaya penanggulangan kebakaran. Hal tersebut diungkapkan oleh informan dari berbagai kelurahan di Jakarta Timur. Alasan lain, dinyatakan oleh informan dari kelurahan di Jakarta Pusat adalah kesulitan mencari harta benda sehingga tidak boleh terbuang sia-sia akibat kebakaran. Seluruh infor- man dari staf kecamatan terpilih di DKI Jakarta mengatakan bahwa masyarakat sangat memerlukan tujuan bersama menghadapi kebakaran. Tujuan tersebut berupa tercipta rasa aman, kebakaran merugikan semua pihak sehingga warga sendiri yang harus menanganinya. Untuk menciptakan visi pencegahan kebakaran yang sama serta untuk meminimalkan jumlah korban dan kerugian material dibutuhkan pengaturan fungsi.

Kebakaran yang merugikan semua pihak termasuk warga, memerlukan penanganan dini. (staf Satpol PP Kecamatan Jakarta Selatan, 28 tahun).

Untuk kepentingan mereka sendiri dan kebersamaan. Saran saya harus lebih banyak sosialisasi masalah pencegahan kebakaran dari instansi yang terkait. Sangat perlu cara-cara, karena sudah ada contoh di beberapa kelurahan sudah ada praktek yang leading sector-nya Sudin Kebakaran Jakarta Timur, peserta prakteknya dari masyarakat. Kelurahan Gedong terutama sudah ada praktek pencegahan kebakaran di tengah masyarakat. (wakil camat, 51 tahun).

Untuk meniminimalkan jumlah korban atau angka material yang habis. (staf kecamatan Jakarta Pusat).

Lima informan dari Sudin Pemadam Kebakaran lima wilayah DKI Jakarta menganggap bahwa masyarakat sangat perlu mempunyai tujuan bersama dan cara-cara menghadapi kebakaran untuk memperkecil kerugian akibat kebakaran. Sehingga tanpa perlu menunggu Sudin PK dan DPK, masyarakat sudah mengetahui tindakan pertama yang harus dilakukan. Yang penting adalah batasan yang dapat dilakukan oleh masyarakat dan yang menjadi kewajiban instansi penanganan kebakaran.

Memperkecil kerugian, jadi tanpa menunggu kita bertindak, dia sudah melakukan upaya terlebih dulu. (staf Sudin Damkar Jakarta Barat, 40 tahun).

Saat ini personil kebakaran kurang, jika terjadi kebakaran, masyarakat yang mengalami kerugian perlu batasan tindakan dengan kewenangan pemadaman awal/dini. Penanganan kebakaran ditentukan oleh penanganan tahap awal tersebut. Masyarakat diberi penyuluhan dengan batasan tahap pemadaman awal/dini. (staf Sudin Damkar Jakarta Pusat, 39 tahun).

Masyarakat memerlukan dorongan yang kuat dalam menghadapi bahaya kebakaran. Hal itu disampaikan oleh seluruh informan penelitian melalui pemberian beberapa contoh lapangan seperti penanaman motivasi oleh pihak kelurahan ke masyarakat agar mematikan listrik rumah bila penghuni bepergian, inspeksi mendadak (sidak) oleh Lurah, Camat, dan pihak PLN ke perusahaan konfeksi di masyarakat, pemberian informasi dampak bahaya kebakaran yang dilanjutkan dengan sosialisasi berbagai upaya pencegahan dan penanggulangan kebakaran melalui pelatihan. Dorongan kuat tersebut dibutuhkan seluruh masyarakat karena kebakaran merugikan masyarakat dan untuk pencegahan dan pengendalian merupakan ke- 
pentingan bersama. Selain itu, lingkungan pemukiman berada di wilayah padat penduduk dengan alur distribusi listrik yang berantakan. Motivasi perlu dilakukan pada masyarakat agar mereka selalu ingat untuk melakukan upaya pencegahan kebakaran, meningkatkan kesadaran menjaga lingkungan aman dari kebakaran. Tanpa dorongan dan dukungan dari tokoh masyarakat dan pemerintah, masyarakat akan bertindak sendiri-sendiri.

Ya, kerugian karena kebakaran besar sehingga perlu sosialisasi sebagai motivator. (wakil lurah, 42 tahun).

Bisa memberikan keterampilan secara mandiri bila terjadi bahaya kebakaran. Tapi ditekankan hanya pada pencegahan kebakaran. Kalau represif sudah diberikan juga langkah-langkah seperti pemberian pelatihan dan sosialisasi. (sekretaris camat, 35 tahun).

Seorang informan dari Sudin Damkar salah satu wilayah di DKI Jakarta menyatakan bahwa motivasi harus ditanamkan ke masyarakat karena motivasi pemerintah umumnya kurang. Masyarakat harus dimotivasi secara terus-menerus agar lebih peduli pada kebakaran. Mereka perlu didukung bersama-sama di lingkungan dan perlu ditimbulkan empati dan kepedulian. Tujuan bersama tersebut perlu ditindaklanjuti dengan penyusunan berbagai langkah kerja dalam menghadapi bahaya kebakaran di lingkungan pemukiman. Selanjutnya, kepada seluruh informan wawancara mendalam ditanyakan, mereka menganggap perlu menyusun berbagai langkah kerja untuk pencegahan kebakaran secara dini. Namun, empat dari 25 informan menyatakan bahwa yang berhak menyusun berbagai langkah tersebut adalah Dinas PK dan atau Sudin PK karena pihak kelurahan belum mempunyai program (1 informan).

Satu informan dari kelurahan Jakarta Barat menganggap penyusunan itu dapat dilakukan tergantung pada sikap kepengurusan RT dan RW. Kebanyakan informan beralasan perlu penyusunan langkah kerja untuk mencegah kepanikan saat terjadi kebakaran, sebagai acuan yang mengarahkan langkah kerja yang dilakukan, terciptanya syarat tanggap darurat kebakaran, masyarakat tahu peran mereka saat terjadi kebakaran di luar peran DPK dan pihak kelurahan.

Bentuk konkrit langkah kerja yang dilakukan kini meliputi penyuluhan; SKKL; BALAKAR; pemberian alat pemadam kebakaran; rapat koordinasi perencanaan Sudin Damkar Wilayah; penyuluhan dan sosialisasi kebakaran; pendirian posko informasi dan bantuan kebakaran; pelatihan kebakaran. Seorang informan dari kelurahan Jakarta Barat mengaku sulit memberikan penyuluhan pada seluruh masyarakat karena hanya dilakukan pada acara PKK. Sasaran terbatas pada RT, RW, tokoh masyarakat, pemuda, dan organisasi lain. Seorang informan dari Sudin Damkar Jakarta Timur menyarankan penyusunan Standar Pelayanan Minimal (SPM) persyaratan kesiapan sumber daya manusia titik pos terdekat, dan response time. Untuk SKKL, Sudin Damkar bertindak sebagai komando dan masyarakat sebagai pelaksana meliputi unsur tokoh masyarakat, pengurus RT dan RW, karang taruna, dan ibu PKK.

Pemberdayaan masyarakat dapat diciptakan melalui pembentukan SKKL yang dilakukan melalui rekruitmen SKKL, pembinaan, pemberian peralatan, dan penyusunan struktur organisasi yang jelas untuk membagi tugas pada saat darurat. Seorang informan dari Sudin Damkar Jakarta Barat mengatakan secara rinci bentuk langkah-langkah kerja tersebut. Sebelum kebakaran, ketua RT mendata jumlah kepala keluarga; bahan dasar konstruksi bangunan rumah, kerapatan bangunan rumah; keberadaan pompa, saluran air, pasir dan jumlah alat pemadam kebakaran. Pada saat dan pasca kebakaran, memanfaatkan anggota BALAKAR yang meliputi seksi logistik, keamanan, pemadaman api, komunikasi, evakuasi. Seorang informan kelurahan Jakarta Timur, mengusulkan bahwa RW menyusun langkah kerja upaya mencegah kebakaran berupa pemberian motivasi dan himbauan kepada warga agar berhati-hati menggunakan listrik, sosialisasi bahaya kebakaran akibat arus listrik dan ledakan kompor.

Jenis kegiatan yang perlu dilakukan masyarakat untuk menciptakan lingkungan aman kebakaran meliputi penyuluhan, sosialisasi, dan himbauan. Kegiatan untuk perilaku aman kebakaran meliputi pemeriksaan instalasi listrik rumah, penggantian kabel usang, mencegah pencurian aliran litrik, pelatihan BALAKAR/SKKL, pemeriksaan berkala dan identifikasi berbagai potensi bahaya kebakaran, serta saling mengingatkan anggota keluarga. Seorang informan dari kelurahan Jakarta Timur menyarankan agar masyarakat menjalankan perintah agama, menjadi orang bertakwa, dan berdoa memohon keselamatan.

Semua informan unsur kelurahan, kecamatan, dan Sudin Damkar bersedia dilibatkan dalam kegiatan pencegahan dan kesiagaan kebakaran karena rasa tanggung jawab sebagai pelayan masyarakat. Ketika ditanyakan kelompok yang perlu dilibatkan upaya mitigasi kebakaran seluruh informan mengatakan semua komponen masyarakat meliputi RT, RW, tokoh masyarakat, unsur PKK, karang taruna, perlindungan masyarakat/hansip, dewan kelurahan, ibu rumah tangga dengan penekanan penduduk di pemukiman kumuh.

Upaya pencegahan kebakaran yang diikuti oleh sebagian besar masyarakat di lingkungan pemukiman meliputi penyuluhan, sosialisasi bahaya dan dampak kebakaran, pelatihan BALAKAR/SKKL; pelatihan untuk ibu rumah tangga, remaja, dan hansip, pemberian tabung gas pemadam kebakaran dan hidran pada RT dan RW; pemeriksaan bangunan berkala setiap bulan, bangunan perdagangan, industri, dan sweeping listrik. Sejak akhir tahun 2007, Kecamatan Johar Baru, Jakarta Pusat melakukan sosialisasi pada murid Taman Kanak-Kanak atau Pendidikan Anak Usia Dini. 
Di setiap gedung pemerintah, kantor, sekolah sudah bersedia menyiapkan tabung pemadam kebakaran. Sudah dibuat sosialisasi kebakaran setiap 1 tahun sekali, ada 50-60 orang yang diundang untuk diberikan penjelasan, mengenai masalah kebakaran misalnya menangani kompor meleduk, mematikan api menggunakan karung. (wakil lurah, 48 tahun).

Untuk masyarakat belum ada, di tingkat Sudin Kebakaran Jakarta Timur mungkin ada. Sasaran pelatihan kelurahan adalah ibu rumah tangga, selama ini, ada anggaran untuk sosialisasi dan pelatihan untuk penanggulangan kebakaran. Sasaran pelatihan Sudin Kebakaran Jakarta Timur adalah remaja. (sekretaris kelurahan, 48 tahun).

Informan dari dua kelurahan di Jakarta Timur menyatakan pelatihan kebakaran Sudin PK Jakarta Timur baru berjalan 2 tahun lalu, informan kelurahan, Jakarta Pusat menyatakan sejak 5 tahun lalu. Di Jakarta Utara, sejak bulan Agustus 2009 lalu, dan di Jakarta Timur sejak tahun 2005. Sudin PK Jakarta Pusat menyatakan bahwa BALAKAR pertama kali terbentuk sekitar tahun 1970. Dua kelurahan di Jakarta Selatan menyelenggarakan pelatihan BALAKAR pada April dan Agustus 2009. Namun, seorang informan dari kecamatan di Jakarta Utara mengaku tidak tahu, dan seorang lagi dari kecamatan di Jakarta Selatan menyatakan kelurahan lebih tahu daripada kecamatan.

\section{Pembentukan BALAKAR/SATLAKAR}

Pada bagian ini ditanyakan tentang BALAKAR/ SATLAKAR, tugas pokok, sumber mendengar istilah BALAKAR/SATLAKAR, kelancaran implementasi di masyarakat. Jika BALAKAR/SATLAKAR sudah mati, ditanyakan waktu terakhir berfungsi dan pembentukan BALAKAR/SATLAKAR, alasan berhenti, dasar hukum pembentukan, kendala penerapan, ketersediaan juknis dan juklak modul pembinaan, jenis pelatihan, dan sejarah pembentukan di lingkungan pemukiman.

Seluruh informan kelurahan, kecamatan, dan Sudin PK pernah mendengar istilah BALAKAR/SATLAKAR. Informan dari Sudin PK di lima wilayah DKI Jakarta tahu arti singkatan Barisan Sukarelawan Kebakaran dan Satuan Tenaga Kebakaran tersebut. Dua informan staf kecamatan pernah mendengar istilah tersebut tetapi tidak tahu artinya dan seorang informan lain dari kecamatan lupa artinya. Seorang informan staf kecamatan menyebut Bahaya Latihan Kebakaran. Seorang informan dari Sudin PK Jakarta Barat mengatakan dulu istilah volunteer kebakaran. Dua informan dari kelurahan salah menyebut istilah BALAKAR menjadi Bantuan Pelaksanaan Bahaya Kebakaran, dan Pelatihan Pemadam Kebakaran. Seorang informan staf kecamatan menambahkan informasi BALAKAR berupa sistem, ketua dan anggota dalam organisasi BALAKAR/SATLAKAR. Mereka telah memperoleh keterampilan dari Sudin
Kebakaran. Di kecamatan belum ada BALAKAR, tetapi di kelurahan sudah ada yang dibantu perangkat kelurahan dengan pelatihan BALAKAR.

Informan dari sebuah LSM di DKI Jakarta pemerhati kebakaran pernah mendengar istilah BALAKAR/SATLAKAR. SATLAKAR berada di tingkat kecamatan yang merupakan singkatan dari Satuan Pelaksana Bahaya Kebakaran. BALAKAR sudah lama berdiri yang diawali dengan SKLK, istilahnya di DKI Jakarta adalah BALAKAR dan wilayah lain adalah SATLAKAR. Regulasi tentang BALAKAR dimiliki oleh Departemen Pekerjaan Umum (PU) dengan Keputusan Menteri (KepMen) No. 10 dan 11, dan DPK dengan Perda No. 8 Tahun 2008. Menurutnya, masyarakat perlu melakukan mitigasi kesiagaan kebakaran untuk mencegah kerugian yang lebih besar. LSM yang dinaunginya dapat menginisiasi pemunculan BALAKAR dari masyarakat. Langkah kepeloporan yang dilakukan adalah menilai berbagai resiko kebakaran, SOP, penyimpanan alat-alat proteksi kebakaran, rute untuk evakuasi, latihan rutin secara berkala, dan evaluasi. Ditanyakan tentang kesediaan informan dari LSM terlibat di dalam BALAKAR, ternyata bersedia menjadi insiator pembentukan BALAKAR.

Empat informan staf kelurahan mengetahui BALAKAR dari spanduk di jalan dan DPK. Seorang informan mengetahui saat menjabat lurah sebelum bekerja sebagai staf kecamatan. Sebagian informan kelurahan mengetahui dari pelatihan dan sosialisasi BALAKAR melalui bukubuku, pamflet, dan brosur-brosur Sudin PK, serta dari Sudin PK ketika meminta bantuan aparat kelurahan merekrut calon anggota BALAKAR. Tiga informan pekerja Sudin PK tahu BALAKAR karena sesuai profesi yang wajib tahu dari Peraturan Daerah (Perda). Namun, dua informan Sudin PK telah tahu sejak tahun 1980-1990-an.

Seluruh informan staf kecamatan dapat menyebutkan tugas pokok BALAKAR meliputi latihan kebakaran Sudin PK; memadamkan api; membantu operasional di lapangan, tapi tidak berwenang mengambil kebijakan atau berbagai langkah konkrit. Dengan demikian, hanya membantu pemadaman api sebelum petugas pemadam tiba. Apabila petugas pemadam datang, mereka tetap membantu memadamkan api, mendukung kinerja pemadam kebakaran, mencegah masyarakat mengganggu pemadam kebakaran di lokasi, ada bagan dan struktursampai di tingkat kelurahan.

Tugas pokok BALAKAR yang diketahui oleh informan staf kelurahan antara lain: menangani kebakaran tingkat kelurahan, dan RW; pionir di masyarakat yang menjadi barisan terdepan penanggulangan kebakaran termasuk memotivasi warga agar mau melakukan upaya pencegahan, dan pemadaman kebakaran; mensosialisasikan bahaya kebakaran melalui penyuluhan dan pelatihan; mitra kerja DPK memadamkan api saat terjadi kebakaran, mempersiapkan alat pemadam kebakaran, mencari sumber air, dan melakukan evakuasi, menginformasikan ke- 
bakaran kepada Ketua RT, RW, dan masyarakat.

Informan dari Sudin PK wilayah DKI Jakarta menyebut tugas pokok BALAKAR sebagai berikut: mencegah kebakaran; menanggulangi atau memadamkan kebakaran; P3K atau menyelamatkan sebelum DPK datang; berperan sebagai regu pemadam kebakaran dengan menggunakan alat yang sederhana dan hydrant; regu pertolongan pertama akan mengevakuasi korban dari areal kebakaran ke area yang aman; memberi informasi yang lebih lengkap kepada petugas kebakaran untuk menyusun strategi pemadaman yang baik. Contoh, memberi informasi sumber air alam dan jalan yang dilalui mobil pemadam kebakaran.

Seluruh informan dari Sudin PK mengatakan BALAKAR telah terbentuk sejak Tahun 2003-2005, tetapi belum merata. Informan Sudin PK Jakarta Timur mengatakan sejak tahun 2005 BALAKAR lebih fokus dengan intensitas yang ditingkatkan. Pembinaan dilakukan di empat sektor Kecamatan Cakung, Pulogadung, Ciracas, dan Makassar guna lebih mendekatkan pelayanan pada masyarakat. Informan dari Sudin PK Jakarta Barat bahkan mengungkapkan BALAKAR sudah ada sejak tahun 1980-an, tetapi berjalan di tempat, belum merata di tiap RW/kelurahan, tetapi sebagian besar tidak tahu waktu terbentuknya, saat ini BALAKAR masih berjalan. Tiga informan kelurahan masih mengingat jelas tahun pembentukan BALAKAR di tahun 2005-2006.

Seluruh informan staf kelurahan dan kecamatan tidak tahu dasar hukum pembentukan BALAKAR mereka menyatakan Sudin PK lebih tahu. Namun, ada informan yang memperkirakan dasar hukumnya yaitu Perda Gubernur tanpa menyebutkan nomor. Informan staf Sudin PK mengetahui dasar hukum yaitu: Perda No. 3 Tahun 1975 tentang Pemukiman; Peraturan Gubernur No. 166 tentang Pembentukan Organisasi BALAKAR; Perda No. 3 Tahun 1992 diganti menjadi Perda No. 8 Tahun 2008 (pasal 141 ayat 2). Dalam wilayah DKI Jakarta dalam upaya mewujudkan partisipasi masyarakat dibentuk suatu Barisan Sukarelawan Kebakaran yang ditetapkan oleh gubernur.

Berbagai kendala pelaksanaan BALAKAR di lapangan menurut informan staf Sudin PK antara lain: tidak ada kecocokan waktu antara masyarakat dan DPK; tidak ada tunjangan anggota BALAKAR sehingga sering drop out; sulit merekrut peserta karena tidak ada sistem tunjangan/gaji sehingga tidak mengikat; profesi anggota BALAKAR karyawan, tetap saat dibutuhkan tidak ada di tempat; beberapa anggota BALAKAR merupakan penduduk musiman/tidak tetap sehingga tiba-tiba dapat pindah rumah. Hal sama dirasakan dua informan staf kelurahan, tidak ada gaji yang diberikan sehingga banyak yang drop out dan sulit mencari anggota baru, ketika kebakaran sulit menemukan anggota BALAKAR di tempat. Seorang informan staf kelurahan lain mengatakan anggota BALAKAR yang telah mengikuti pelatihan cenderung tidak menyebarkan informasi yang diperoleh ke orang lain. Selama ini, sebagian besar informan staf kelurahan merasa tidak menemukan hambatan implementasi BALAKAR, karena masyarakat bersikap pro-aktif dan berjalan lancar.

Masalah drop out anggota BALAKAR diatasi dengan merekrut personil yang mudah dicari seperti kelompok perempuan/ibu-ibu dan remaja/pemuda. Seorang informan staf kelurahan berpendapat sulit memecahkan masalah insentif, karena itu harus dikembalikan ke pribadi orang yang bersangkutan. Pemecahan masalah yang sulit itu juga dikemukakan oleh seorang informan kelurahan lain. Kebakaran adalah masalah irasional sehingga diperlukan kesadaran tinggi dari masyarakat, jangan selalu mengukur segala sesuatu dengan uang/materi.

Secara umum, seluruh informan merasakan hubungan antara mitigasi kebakaran dan motivasi masyarakat di pemukiman dengan bentuk partisipasi nyata. Hal tersebut akibat peningkatan kesadaran masyarakat terhadap dampak kebakaran. BALAKAR memberikan pencerahan dan motivasi bagi masyarakat, cara penanggulangan sehingga tercipta lingkungan peduli bahaya kebakaran. Pembentukan BALAKAR meningkatkan kepedulian masyarakat terhadap bahaya kebakaran setelah diberikan alat proteksi kebakaran. BALAKAR adalah model kesiagaan kebakaran yang dibentuk oleh dan untuk masyarakat. Hanya seorang staf Sudin PK Jakarta Selatan yang belum merasakan hal tersebut karena kurang pembinaan dan pemantauan BALAKAR oleh pemerintah.

Mayoritas informan staf Sudin PK menganggap masih ada peraturan dalam pembinaan BALAKAR yang kurang. Salah satu adalah kesejahteraan BALAKAR yang dibebankan pada APBD yang belum jelas. Anggota BALAKAR juga mempunyai keluarga yang harus diberi nafkah, sehingga keberadaan honor amat diperlukan. Akibatnya sulit memobilisasi anggota BALAKAR karena tidak ada kompensasi yang jelas.

Peraturan pembinaan BALAKAR yang ada saat ini dirasakan cukup baik oleh kebanyakan informan staf kelurahan. Mereka hanya menjalankan aturan yang telah ditetapkan oleh DPK/Sudin PK. Tetapi, seorang informan staf kecamatan di Jakarta Barat menilai yang kurang hanya honorariumnya saja. Pemberian honor dapat meningkatkan semangat kerja dan rasa tanggung jawabnya.

Sejauh ini tidak ada masalah, yang kurang hanya honorariumnya saja. Karena mereka tidak diberikan honor hanya bersifat sukarela, tetapi kalau mereka diberikan honor bisa menjadi meningkat, jadi lebih semangat, dan bertanggung jawab. (sekretaris kecamatan, 35 tahun).

Informan staf kecamatan umumnya mengatakan bahwa kantor kecamatan tidak menyimpan modul/juknis pembinaan BALAKAR karena dipegang sektor lain DPK dan Sudin PK. Dulu ada kecamatan yang pernah diberi pedoman tersebut, tetapi kini hilang. Informan yang 
menyatakan mempunyai pedoman tersebut meliputi sistem tata cara penanganan, struktur organisasi, dasar hukum, dan pola penanganan. Semua informan staf Sudin PK mengaku mempunyai pedoman/juknis pembinaan BALAKAR meliputi pedoman SKLK, SOP BALAKAR, SOP pemeriksaan berkala, modul pelatihan BALAKAR, dan booklet. Pedoman/modul/juknis pembentukan dan pembinaan BALAKAR diakui oleh kebanyakan informan staf kelurahan. Pedoman tersebut mengacu pada aturan DPK, tetapi informasi pedoman itu belum sampai ke seluruh aparat kelurahan. Programprogram terkait pembentukan dan pembinaan BALAKAR di wilayah tempat tinggal informan biasanya dalam bentuk sosialisasi dan pelatihan. Kegiatan tersebut dilakukan setahun sekali dengan narasumber dari Sudin PK. Aparat kelurahan dan RW hanya menyiapkan sumber daya manusia, seluruh kegiatan pelatihan teori dan praktek ditangani langsung oleh DPK/ Sudin PK.

Sejumlah informan wawancara mendalam staf kelurahan, enam orang menyatakan kegiatan BALAKAR berjalan sampai kini. Sebagian kecil mengetahui waktu pembentukan sejak tahun 2006-2007. Pelatihan BALAKAR dilakukan dengan frekuensi setahun sekali, tetapi mereka tidak tahu program dan teknis pelaksanaan karena pihak kelurahan hanya menyediakan peserta pelatihan, Sudin PK/DPK sebagai penyelenggara pelatihan BALAKAR. Dua orang informan masing-masing dari Kelurahan Kayumanis dan Kebon Kacang mengetahui program dan teknsi pelatihan yang diberikan. Berbagai program kegiatan BALAKAR dilakukan dalam bentuk pelatihan, sosialisasi, praktek, dan penyuluhan. Secara teknis program tersebut disusun oleh Sudin PK/DPK dan pihak Sudin PK/DPK meminta ijin ke kelurahan untuk menyiapkan tempat dan merekrut warga.

Umumnya pihak kecamatan kurang mengetahui waktu, program dan teknis pelaksanaan kegiatan BALAKAR, karena mereka menyerahkan kegiatan tersebut sepenuhnya kepada pihak kelurahan. Mereka hanya mengetahui jenis peserta yang terlibat dan pelaksana kegiatan.

Menurut pihak Sudin PK, frekuensi kegiatan, bentuk kegiatan, dan teknis pelaksana kegiatan BALAKAR, program kegiatan meliputi pelatihan teori, praktek, dan simulasi. Materi pelatihan meliputi pengetahuan tentang kebakaran meliputi fenomena kebakaran, penyebab kebakaran, mekanisme perpindahan kebakaran, cara penanganan dini, dan cara komunikasi kebakaran pada dinas kebakaran, kapan dilakukan dan bagaimana komunikasi. Pelatihan dilakukan di kantor kelurahan dengan peserta para Ibu Peningkatan Peran Wanita menuju Masyarakat Sejahtera. Materi praktek adalah pemadaman api dengan alat sederhana, alat pemadam api ringan (APAR), dan pompa portable. Simulasi gladi lapang, gladi rencana operasi pada saat awal kejadian kebakaran sambil menunggu bantuan pemadam kebakaran.
Pembinaan BALAKAR dilakukan oleh kepala sektor kecamatan yang mempunyai data jumlah sarana pemadam kebakaran, jumlah BALAKAR di tiap kecamatan. Sudin PK Jakarta Barat menyatakan belum membina BALAKAR sampai kini akibat jumlah yang sedikit. Pelaksanaan kegiatan BALAKAR dilakukan di wilayah yang rawan kebakaran dengan prosedur yang sama dengan penjelasan pihak kelurahan.

\section{Partisipasi Masyarakat}

Tentang partisipasi masyarakat dalam mitigasi kesiagaan kebakaran, seluruh informan menyatakan perlu. Bahkan seorang informan staf kelurahan yakin masyarakat sudah tahu secara otomatis. Alasan partisipasi yang diperlukan tersebut adalah bahwa masyarakat jangan hanya mengandalkan BALAKAR dan petugas pemadam kebakaran, tapi harus merencanakan tindakan darurat dari dan untuk masyarakat. Untuk kepentingan bersama yang menyangkut hajat hidup orang banyakan bahaya kebakaran, mengingat lingkungan yang padat, jumlah penduduk yang padat, dan lingkungan pemukiman yang sempit. Bentuk partisipasi masyarakat yang dilakukan antara lain adalah mengikuti sosialisasi, pelatihan dan penyuluhan bahwa kini telah dibentuk organisasi Satuan Koordinator Pelaksana (Satkorlak), Satuan Koordinator Masyarakat (Satkormas), dan Satuan Dinas Masyarakat (Satdinmas) yang bertugas membantu masyarakat ketika terjadi bencana. Sebagai contoh, penyediaan dapur umum dan air Perusahaan Air Minum (PAM). Sebagian besar informan kelurahan menyatakan belum membentuk organisasi/kegiatan khusus penanggulangan dan pencegahan kebakaran di lingkungan pemukian karena cukup memberdayakan RT, RW, dan karang taruna.

Dua informan kecamatan menganggap Satkorlap dan PBP merupakan salah satu organisasi yang berperan ketika terjadi bencana banjir, kebakaran, dan gempa serta BALAKAR. Informan kecamatan yang mengaku belum membentuknya dengan alasan keterbatasan dana Sudin PK, pembentukan organisasi membutuhkan dasar hukum dan persetujuan pimpinan tingkat propinsi. Selain itu, masyarakat menganggap hal tersebut urusan pemerintah dan belum ada program khusus akibat skala yang kecil.

Jika kelak dibentuk model mitigasi kesiagaan kebakaran berbasis masyarakat, seluruh informan bersedia terlibat menjadi relawan sebagai wujud tanggung jawab anggota masyarakat. Usulan bentuk model itu antara lain: mempunyai mekanisme seperti BALAKAR membuat forum di tingkat RT dan RW. Penyusunan model bertahap berbasis tingkat RW, dan tingkat RT sehingga makin mengrucut; membuat kelompok kecil 3-4 orang yang diketuai Ketua RT untuk melakukan penyuluhan kebakaran ke masyarakat; pelatihan bagi remaja di RW melalui program pemberdayaan masyarakat upaya pencegahan dan penanganan kebakaran; sosialisasi bahaya ke- 
bakaran pada masyarakat tentang penanganan ledakan kompor, pemadaman api dengan karung basah, membentuk tim penanggulangan bencana kebakaran memberikan arahan dan masukan bahaya kebakaran, penanggulangan kebakaran, cara-cara evakuasi bahaya kebakaran, cara menyadarkan orang dan memberikan efek psikologis, menghadapi kebakaran. Ini terdiri dari unsurunsur remaja, karang taruna, anggota ketentraman dan ketertiban (Tramtib), pengurus RT, RW, tokoh masyarakat, dan remaja mesjid. Membangun studio radio yang selalu memperingatkan mayarakat untuk waspada bahaya kebakaran, selalu memperingatkan masyarakat melalui di musholla tindakan pencegahan kebakaran.

Jika tersedia dana, perlu insentif kepada relawan yang terlibat sehingga dapat mendorong motivasi kerja. Namun, ada yang berpendapat tidak perlu model mitigasi kebakaran berbasis masyarakat. Sebaiknya, hal tersebut dikembalikan ke masyarakat karena mereka mempunyai aturan sendiri. Di samping itu, model BALAKAR yang ada mempunyai mekanisme yang baik dan berbasis masyarakat. Yang perlu ditingkatkan adalah intensitas sosialisasi dan pelatihan sehingga organisasi tersebut lebih dikenal masyarakat luas. Organisasi yang banyak membingungkan masyarakat karena tumpang tindih dan pemborosan.

\section{Pembahasan}

Secara umum seluruh informan dari unsur aparat kelurahan, kecamatan, staf Sudin PK, DPK, akademisi, pengelola PD Pasar Jaya, dan masyarakat menyatakan penting mempunyai tujuan pencegahan kebakaran bersama. Latar belakang tujuan yang penting tersebut adalah rasa kebersamaan yang kuat menghadapi bahaya kebakaran, persamaan persepsi kebakaran merugikan harta dan nyawa. Ada kesamaan pendapat tentang keperluan tujuan bersama tersebut dari kalangan informan aparat pemerintah dan masyarakat. Semua memahami dampak kebakaran yang tinggi secara moril, materil dan ketenangan jiwa. Dorongan dan motivasi kuat dibutuhkan untuk menghadapi bahaya kebakaran agar tercipta rasa aman, tanpa motivasi yang kuat tidak terjadi perubahan perilaku yang diharapkan. Motivasi merupakan respons dalam diri yang mempengaruhi perubahan perilaku individu akibat stimulus dari luar. ${ }^{5}$

Motivasi yang tinggi terjadi berdasarkan tujuan bersama terhindar dari bahaya kebakaran dapat mendorong perilaku mencegah kebakaran. Berbagai contoh perilaku mencegah kebakaran yang dilakukan masyarakat dan yang diusulkan adalah pelatihan dan simulasi BALAKAR pemadaman api dan pemakaian listrik dan kompor yang tepat, menerapkan himbauan dan penyuluhan yang diberikan aparat kelurahan dan Sudin PK/DPK, saling mengingat sesama warga untuk berperilaku aman memakai listrik dan kompor. Sementara, berbagai langkah kerja yang runut yang men- jadi temuan studi ini tampak masih perlu dipertajam karena identik dengan berbagai contoh kegiatan di atas.

Masyarakat DKI Jakarta telah menggunakan peralatan teknologi yang canggih dalam melaporkan kejadian kebakaran ke Sudin PK/DPK melalui pemakaian smart alarm. Alat ini tersambung langsung ke kantor Sudin PK/DPK sehingga dapat menilai kebenaran berita kebakaran dengan menelpon langsung ke lokasi kejadian. Namun, masyarakat Kota Bogor dan Tangerang belum menggunakan alat tersebut karena belum tersedia. Mungkin karena wilayah risiko kebakaran di sana lebih rendah daripada DKI Jakarta. Namun, kebakaran di pasar harus mendapat perhatian karena risiko tinggi akibat pemakaian arus listrik melebihi jatah dan instalasi listrik yang tidak rapi. Sementara, peralatan proteksi kebakaran di pasar sangat sederhana yaitu APAR, dan tidak ada smart alarm. Di Kota Tangerang, smart alarm lebih banyak ditempatkan di RS, hotel, dan rumah dinas instansi pemerintah daripada di lingkungan RW.

Implementasi berbagai tugas khusus pada saat kebakaran seperti evakuasi korban kebakaran, dan perobohan rumah yang mudah terbakar dilakukan spontan oleh masyarakat. Hal tersebut didorong oleh rasa kebersamaan yang tinggi. Di wilayah pemukiman yang mempunyai BALAKAR/SATLAKAR, tugas khusus dilakukan karena fungsi BALAKAR antara lain membantu melakukan tugas khusus ketika terjadi kebakaran. BALAKAR mempunyai atribut rompi sehingga dapat dibedakan dari masyarakat biasa.

Berbagai temuan memperlihatkan bahwa masyarakat menyadari bahaya kebakaran sehingga bersedia terlibat dalam kegiatan mitigasi kebakaran berbasis masyarakat. Tanpa disadari masyarakat telah melakukan upaya pencegahan kebakaran sebagai bagian dari mitigasi kesiagaan kebakaran selain BALAKAR. Namun, kegiatan yang dilakukan bukan merupakan model khusus yang diakui secara formal, tetapi tindakan pencegahan yang merupakan bagian model berbasis masyarakat. Selama ini, setting pemadam kebakaran lebih ditekankan pada upaya pemadaman api sejak informasi kebakaran diterima sampai padam. Pelayanan pos pemadam kebakaran yang bersifat darurat menuntut ketepatan dan kecepatan yang mengacu pada Keputusan Mentri Pekerjaan Umum RI tentang Ketentuan Teknis Manajemen Penanggulangan Kebakaran di Perkotaan. ${ }^{6}$ Di wilayah rawan kebakaran dibangun pos kebakaran dengan penempatan beberapa orang petugas. Sebagian besar masyarakat menganggap tugas pemadam kebakaran adalah memadamkan api, bukan mencegah dan menyiagai kebakaran. Hanya sebagian kecil masyarakat yang mengetahui peran pencegahan kebakaran.

\section{Pembentukan BALAKAR/ SATLAKAR}

Pengetahuan informan aparat kelurahan, kecamatan, RW, dan Sudin PK/DPK tentang BALAKAR/SAT- 
LAKAR sebaiknya dibandingkan dengan masyarakat awam yang lebih mengetahui karena terlibat dalam proses sosialisasi dan pelatihan BALAKAR. Keterlibatan tersebut termasuk rekrutmen calon anggota, dan bagian pekerjaan rutin di kantor pemadam kebakaran. Namun, masih ada informan kelompok ini yang belum tepat menyebutkan kepanjangan BALAKAR dan SATLAKAR.

Seluruh informan wakil masyarakat Kota Tangerang dan sebagian besar informan wakil masyarakat Kota Bogor belum pernah mendengar istilah BALAKAR/SATLAKAR dan dasar hukum pembentukan. Namun informan wakil masyarakat Kota Depok mengetahui istilah BALAKAR/ SATLAKAR. Ditemukan beberapa kendala yang menghambat kelancaran implementasi BALAKAR/ SATLAKAR di masyarakat. Kendala itu adalah motivasi anggota yang rendah akibat tidak ada insentif yang memicu drop out. Anggota cenderung tidak menyebarluaskan informasi yang diperoleh ketika mengikuti pelatihan dan simulasi penanggulangan kebakaran, sehingga ketika keluar tidak ada yang menggantikan, status penduduk musiman menyebabkan perpindahan tanpa alasan dan akhirnya drop out, kehadiran anggota yang rendah pada saat terjadi kebakaran.

Anggota BALAKAR umumnya adalah kaum pria yang bekerja di luar rumah sehingga tidak selalu ada di rumah, kecuali para ibu rumah tangga. Masalah inti pelaksanaan organisiasi BALAKAR adalah banyak anggota yang berhenti tanpa alasan karena tidak ada honor. Kendala menjalankan kegiatan organisasi BALAKAR adalah dana $(22 \%)$, di samping kesadaran masyarakat yang rendah. ${ }^{7}$ Pemberian honor dapat meningkatkan motivasi dan kesadaran masyarakat sebagai anggota BALAKAR. Meskipun dinamika anggota BALAKAR tinggi, tapi honor yang rendah sekalipun, dapat menarik minat menjadi anggota BALAKAR sehingga tidak terjadi kekosongan.

Temuan studi ini juga sesuai penelitian Rahmat, ${ }^{8}$ tentang persepsi dan partisipasi masyarakat dalam penanggulangan kebakaran di Kelurahan Galur, Jakarta Pusat. Pola rekruitmen anggota baru BALAKAR masih belum jelas. Anggota senior ingin melakukan kaderisasi, tetapi mereka menyadari pekerjaan pemadaman kebakaran berisiko tinggi sehingga ada ketakutan menerima anggota baru yang belum pernah mengikuti pelatihan. Pemecahan masalah tersebut, perlu mempertimbangkan alokasi anggaran honor anggota pada Perda BALAKAR untuk meningkatkan motivasi menjadi anggota BALAKAR. Modifikasi perilaku dapat dilakukan melalui pemberian reward positif seperti uang dan hadiah.

Implementasi fungsi BALAKAR di masyarakat yang terlihat lebih besar dalam memadamkan api berarti lebih berperan ketika kebakaran telah terjadi. Padahal, risiko kebakaran dapat diminimalisir melalui tindakan pencegahan. Porsi peran organisasi BALAKAR adalah bidang pencegahan kebakaran sesuai kaidah mitigasi kesiagaan.
Upaya pencegahan lebih menguntungkan daripada pengendalian kebakaran karena pencegahan dapat menekan kasus kebakaran menjadi nol. Hal in merupakan hasil penelitian yang perlu diangkat ke permukaan, sehingga peran organisasi BALAKAR dalam mitigasi kesiagaan kebakaran harus lebih dimaksimalkan daripada peran pengendalian kebakaran.

\section{Model Mitigasi Kebakaran}

Studi kualitatif ini merumuskan model mitigasi kesiagaan kebakaran berbasis masyarakat berupa pelaksanaan organisasi BALAKAR/SATLAKAR, pelatihan dan simulasi upaya pencegahan dan pengendalian kebakaran termasuk tugas khusus, pertemuan rutin di tingkat RW/RT. Kegiatan tersebut telah berjalan cukup lama di masyarakat. Kesadaran dan motivasi yang tinggi mendorong masyarakat bersedia melakukan hal tersebut dalam kehidupan sehari-hari. Bahkan, seluruh informan bersedia terlibat menjadi relawan atau petugas penyuluh lapangan. Namun, mereka mengharapkan honor terutama anggota masyarakat yang tidak bekerja. Masyarakat mempunyai persepsi yang baik terhadap masalah kebakaran seperti terlihat dari partisipasi mereka yang cukup tinggi. Budaya partisipasi masyarakat dalam mencegah kebakaran telah ada, tetapi belum didukung kebijakan program sosialisasi penanggulangan kebakaran sinambung yang melibatkan masyarakat yang berpengalaman dalam penyusunan program. ${ }^{8}$

Organisasi BALAKAR/SATLAKAR yang telah berjalan sejak tahun 2006 melakukan pelatihan, simulasi, dan penyuluhan bagi remaja tentang bahaya kebakaran, pencegah, dan penanggulangan kebakaran; Membentuk model yang sistematis/berjenjang mulai dari tingkat atas (DPK), Sudin P, ke bawah meliputi kecamatan, kelurahan, RW, dan RT yang berwenang melakukan upaya pencegahan pengendalian, dan pasca kebakaran; selalu memperingatkan masyarakat untuk selalu waspada bahaya kebakaran.

Membentuk masyarakat waspada kebakaran yang mentetapkan SOP penanganan api dengan simulasi contoh sosialisasi langkah kerja yang harus dilakukan pada ledakan kompor meliputi melapor ke RW dan pos pemadam kebakaran sambil berupaya memadamkan api menggunakan karung goni basah. Tiap RW wajib mempunyai minimal satu unit alat pemadam api yang disediakan secara gratis oleh DPK. Juga dilakukan pemutaran video tentang bahaya kebakaran melalui kelompok pengajian atau arisan ibu PKK, pembangunan jalan masuk lingkungan perumahan yang mudah dilalui mobil pemadam, penempatan hidran di tepi jalan yang mudah diakses. Seluruh kegiatan community ini dipantau setiap enam bulan oleh RW, kelurahan, dan kecamatan.

Memberdayakan kelompok remaja sebagai pemadam api dini saat kebakaran dengan memakai sistem ronda. 
Tiap RT dapat mengirimkan seorang remaja yang setiap minggu secara berkelompok mengontrol rumah dari risiko kebakaran dengan sistem ronda. Mereka mendapat pakaian seragam khusus seperti BALAKAR dan insentif hasil swadaya masyarakat, misalnya Rp 1000,-/KK. Selain itu, disarankan agar tiap rumah mempunyai satu tabung pemadam kebakaran.

Temuan di atas mengindikasikan kebutuhan model yang memberdayakan organisasi BALAKAR/SATLAKAR di masyarakat sambil membenahi SOP yang sudah ada agar berfungsi lebih besar dan berperan dalam mitigasi kesiagaan kebakaran, dan memperbaiki tingkat kesejahteraan anggota. Pembentukan model baru cenderung membingungkan masyarakat karena model yang sudah ada belum berjalan lancar bahkan ada yang mati, di samping menghabiskan dana besar karena memulai dari nol.

Namun, apabila tersedia dana yang cukup besar, dapat dipilih alternatif pembentukan komunitas yang selalu waspada kebakaran dengan memasukkan organisasi BALAKAR/SATLAKAR sebagai sumber daya manusia. Beberapa peraturan dalam Perda tentang BALAKAR perlu disesuaikan dengan kondisi saat ini. Strategi yang diterapkan di berbagai negara lain antara lain Amerika Serikat memberlakukan strategi pencegahan di dalam rumah penduduk berupa memasang instalasi alarm di tiap rumah yang mempunyai anak balita, dan atau lansia; mengembangkan program pendidikan kebakaran termasuk jaringan alarm, rancangan pemasangan alat penyelamatan diri, pemakaian sumber api yang aman dalam rumah tangga, penyimpanan bahan mudah terbakar yang aman, pemasangan sumber api dan penerangan yang jauh dari anak dan upaya promosi kurikulum keselamatan kebakaran di sekolah, organisasi kepemudaan, dan pendidikan senior. ${ }^{9}$

\section{Kesimpulan}

Masyarakat membutuhkan model berbasis masyarakat mitigasi kesiagaan kebakaran meliputi tujuan bersama dan dorongan/motivasi dalam mencegah bahaya kebakaran, keinginan terlibat dalam kegiatan sebagai relawan penyuluh lapangan. Mayoritas masyarakat mengenal organisasi BALAKAR dan fungsi relawan yang menangani kebakaran daripada pra-kebakaran. Kendala yang ditemukan adalah tidak tersedia honor sehingga memicu angka drop out yang tinggi, serta status bekerja dan penduduk musiman. Akibatnya, organisasi ini tidak berjalan karena banyak anggota yang berhenti dan sulit merekrut anggota baru. Namun, dengan pembenahan pada Perda tentang BALAKAR khususnya tentang kesejahteraan diharapkan dapat meningkatkan komitmen dan loyalitas. Secara tidak langsung masyarakat melakukan upaya pencegahan kebakaran yang terkait mitigasi kesiagaan kebakaran. Seperti mengikuti simulasi, penyuluhan, dan pelatihan bahaya kebakaran, serta menjadi anggota BALAKAR/SATLAKAR yang belum diseragamkan sehingga sesuai ketentuan di masyarakat. Kota Depok, dan DKI Jakarta melaksanakan BALAKAR hampir merata, tetapi Kota Tangerang dan Bogor hampir tidak mempunyai BALAKAR yang diduga berhubungan dengan jumlah RW Siaga yang rendah. Alternatif model berbasis masyarakat dipilih adalah memberdayakan BALAKAR. Mengingat program yang sudah berjalan dan dikenal masyarakat sehingga diharapkan lebih mudah diterima masyarakat karena sudah menjadi bagian dari program pembangunan di beberapa wilayah. Dukungan kuat dari masyarakat dalam melaksanakan organisasi BALAKAR menentukan kelancaran pelaksanaan nantinya di lapangan.

\section{Saran}

Berdasarkan temuan studi maka disarankan agar dilakukan penelitian kajian/review SOP, modul pelatihan, juknis/juklak tentang BALAKAR pada tahun kedua nanti. Tujuan menilai kekurangan dan kelebihan perangkat manajemen BALAKAR demi kesempurnaan implementasi BALAKAR nantinya. Setelah itu, dilanjutkan dengan revisi dan ujicoba seluruh perangkat ini, dan diakhiri sosialisasi dan ujicoba model BALAKAR menggunakan pedoman, modul pelatihan, dan juknis yang telah direvisi di suatu wilayah tertentu dalam suatu multisenter studi sebelum akhirnya akan menjadi program nasional pada masa yang akan datang.

\section{Daftar Pustaka}

1. Walthur C. The disaster management cycle. [diakses tanggal 22 Januari 2008].Diunduh dari: http://www.grdc.org/uem/disaster/1-dm_cycle.html.

2. Masyarakat Profesi Proteksi Kebakaran Indonesia. Fire risk assesment masyarakat kelurahan penjaringan Jakarta Utara. Jakarta: 2008.

3. Setiarini Asih. Laporan penelitian studi kualitatif peran LSM dalam mitigasi dan kesiapsiagaan bencana kebakaran di DKI Jakarta. Depok: Pusat Kajian Gizi dan Kesehatan FKM UI; 2008.

4. Dinas Pemadam Kebakaran Propinsi DKI Jakarta. 2004. Modul I konsep sistem ketahanan lingkungan terhadap bahaya kebakaran. Jakarta: Dinas Pemadam Kebakaran Propinsi DKI Jakarta; 2004.

5. Skinner BF. Science and human behavior. New York: Free Press; 1953.

6. Departemen Pemukiman dan Prasarana Wilayah. Keputusan menteri negara pekerjaan umum RI No. 11/KPTS/2000 tentang ketentuan teknis manajemen penanggulangan kebakaran di perkotaan. Jakarta; 2000.

7. Mimin. Laporan akhir pemantapan model pemberdayaan masyarakat dalam penanggulangan kebakaran dengan sistem BALAKAR. Jakarta: Badan Penelitian dan Pengembangan, Departemen Pemukiman dan Prasarana Wilayah; 2004.

8. Rahmat K. Laporan utama hasil penelitian kajian persepsi dan partisipasi masyarakat dalam penanggulangan kebakaran. Majalah Media. 2006; 113 (12) Tahun IV.

9. Minnesota Department of Health. Best practices to prevent home fires. [diakses tanggal 12 Februari 2010]. Diunduh dari: www.health.state.mn.us/injury/best/best.cfm. 